\title{
Prognostic role of TET2 deficiency in myelodysplastic syndromes: A meta-analysis
}

\author{
Yun Lin ${ }^{1}$, Zhijuan Lin ${ }^{1}$, Kun Cheng ${ }^{2}$, Zhihong Fang ${ }^{1}$, Zhifeng Li ${ }^{1}$, Yiming Luo ${ }^{1}$ and \\ Bing $X \mathbf{u}^{1}$ \\ ${ }^{1}$ Department of Hematology, The First Affiliated Hospital of Xiamen University, Xiamen, P.R. China \\ ${ }^{2}$ Thoracic Department, People's Hospital Affiliated to Fujian University of Traditional Chinese Medicine, Fuzhou, P.R. China \\ Correspondence to: Yiming Luo, email: lym8709790@aliyun.com \\ Bing $X u$, email: xubingzhangjian@126.com \\ Keywords: myelodysplastic syndrome, TET2 mutation, prognosis, meta-analysis \\ Received: December 14, $2016 \quad$ Accepted: March 22, $2017 \quad$ Published: April 18, 2017 \\ Copyright: Lin et al. This is an open-access article distributed under the terms of the Creative Commons Attribution License 3.0 \\ (CC BY 3.0), which permits unrestricted use, distribution, and reproduction in any medium, provided the original author and source \\ are credited.
}

\section{ABSTRACT}

Tet methylcytosine dioxygenase 2 gene (TET2) is one of the most frequently mutated gene in myeloid neoplasm, but the prognostic role of TET2 aberrations in myelodysplastic syndromes (MDS) remains unclear. Therefore, we performed a metaanalysis. Fourteen eligible studies with 1983 patients were included in this metaanalysis. Among these, 2 studies evaluated the impact that the TET 2 expression level had on the prognosis. The combined hazard ratios (HR) estimated for overall survival (OS) was $1.00(95 \% \mathrm{CI}: 0.74$ to $1.37 ; \mathrm{p}=0.989)$ when comparing those with TET2 mutations with those without. Among the patients treated with hypomethylating agents (HMAs) or hematopoietic stem cell transplantation (HSCT), the pooled HR for OS was 1.02 (95\% CI: 0.77-1.35, p=0.89) and 1.54 (95\%CI: 0.69 to 3.44; p=0.29), respectively. We also conducted an analysis of the response rate to HMAs, and the OR was 1.73 (95\%CI: 1.11 to 2.70; $p=0.016$ ). Additionally, subgroup analyses showed the pooled HR for OS was 0.93(95\%CI: 0.44 to $1.98 ; \mathrm{P}=0.849$ ) in WHO-classified CMML patients and $1.02(95 \% \mathrm{CI}: 1.02$ to $3.46 ; \mathrm{p}=0.042)$ in studies evaluated TET2 expression level. The analysis suggested TET2 mutations had no significant prognostic value on MDS. However, the response rates to HMAs were significantly different between those with and without TET2 mutations, and the low expression level of TET2 gene was significantly associated with a poor OS in MDS patients.

\section{INTRODUCTION}

Myelodysplastic syndromes (MDS) are a group of heterogeneous clonal diseases that originate in hematopoietic stem cells and are characterized by ineffective hematopoiesis and a high risk of transformation to acute leukemia [1-3]. The current prognostic scoring systems for patients with MDS are mainly based on karyotype abnormalities [4]. Recently, with the development of next-generation sequencing, it has become possible to identify new genomic aberrations. Increasing number of genomic aberrations have been reported to contribute to the development, progression and prognosis of myeloid neoplasms $[5,6]$. Additionally, with the advances in therapeutic methods in MDS, some novel genomic aberrations have been reported to predict the effectiveness of specific treatment. Hence, genomic aberrations may offer more precise cancer phenotypes and more accurate estimations of the prognosis of MDS patients. Among these, the TET2 gene is one of the most frequently mutated genes in MDS and CMML. However, the prognostic significance of TET2 aberrations in MDS remains unclear. Although chronic myelomonocytic leukemia (CMML) has been eliminated from the MDS category by WHO classification, the WHO classification does not have any significant changes in the criteria for diagnosing CMML and most clinical studies still divide patients according to the FAB suggestions [7]. Therefore, in this report, we focus on the influence of TET2 mutations have on clinical prognosis of MDS and CMML patients. 
The TET2 gene is a candidate tumor suppressor gene that resides at chromosome $4 \mathrm{q} 24$, and encodes a protein that catalyzes the conversion of the modified DNA base 5-methylcytosine (5mc) to 5-hydroxymethytosine [8-10]. Mutations in TET2 gene were first identified in myeloid neoplasm, and they have been reported in 19-26\% of MDS cases and 50\% of CMML cases [11-19]. However, the precise role of TET2 mutations in the prognosis of MDS patients remains controversial. O.Kosmider et al (2009b) [16] reported on TET2 mutations in 88 patients with MDS and found that TET2 mutations are an independent favorable prognostic factor in MDS. O.Kosmider et al (2009a) [15] suggested that TET2 mutations were frequent adverse events in CMML. SMITH et al (2010) [12] reported that TET2 mutations had no prognostic value on patients with MDS and CMML and Kim et al (2015) [20] indicated that TET2 mutations were poor prognostic factor in patients with MDS. Hence, to gain full insight into the prognostic value of TET2 mutations in patients with MDS, we performed this meta-analysis.

\section{RESULTS}

\section{Study characteristics}

As shown in Figure 1, 332 records were obtained by a systematic literature search. Three records were identified through relevant references. After excluding of 160 duplicates, 175 records remained for further screening. By reading the titles and reviewing abstracts, we excluded unrelated studies $(n=134)$ and studies that were not performed on adults $(n=4)$. Thus, 37 records remained for full-text screening. After carefully reading the full texts, 23 studies were eliminated due to insufficient data. Ultimately, 14 studies [12, 15, 16, 20-30] including an article [29] and a letter to the editor [20] were obtained and included in the meta-analysis.

\section{Characteristics of the included studies}

Fourteen studies covering a total of 1983 patients were included in the meta-analysis. The characteristics are listed in Table 1 . The 14 included studies were published between 2009 and 2015 and included 395 TET2 mutations and 141 TET2 low gene expression level cases. All 14 eligible studies were retrospective studies. The sample size ranged from 39 to 439 and the frequency of TET2 mutations in the included articles varied between 12.64 and $50.0 \%$. After excluding studies that focused only on CMML patients, the frequency of TET2 mutations ranged from $12.64 \%$ to $27.23 \%$. The results were similar to those of studies [13, 14, 17, 19]. Scopim-Ribeiro et al (2015) [22] included patients with both de novo AML and MDS, however, only patients with MDS were included in the meta-analysis. The median age in the eight studies [12, $15,16,22,23,25-27]$ was older than 60 years old, the median age was younger than 60 years old in four studies
$[20,21,24,28]$ and the median age was not available in the other two studies $[29,30]$. Patients in 10 eligible studies [12, 14, 20-27] were classified by WHO criteria, patients in 3 studies [28-30] were classified by FAB criteria and patients in KOSMIIDER et al (2009) [16] were classified by both WHO and FAB criteria. Patients in 2 studies [27, 30] were treated with HMAs, patients in two other studies [12,16] were treated with either chemotherapy or transplant or supportive treatment, patients in two further studies [26, 28] were treated with stem-cell transplant, patients in Kim et al (2015) [20] were treated with either HMT or SCT or intensive chemotherapy, and patients in two studies $[22,23]$ did not receive any treatment, the treatment description was not available in some studies [15, 21, 24, 25, 29]. The median overall score of NOS results of the included studies was 7.5 (range 6-9), which indicated that the methodological quality was high (Table 2).

\section{Prognostic impact of TET2 mutations in patients with MDS}

We aimed to analyze two primary end points (OS and EFS) to investigate the prognostic impact of TET2 mutations on MDS patients. However, after extracting useful data from the included studies, we were only able to analyze the prognostic impact of TET2 mutations on the OS because of a lack of data on EFS. We evaluated 12 studies $[12,15,16,20,21,24-30]$ with a total of 1726 patients. The overall HR for the OS was $1.00(95 \%$ CI: $0.74-1.37$ with a p-value of $0.989, \mathrm{I}^{2}=68.9 \%$ ) in MDS patients with TET2 mutations compared to those without (Figure 2). These data indicated that the TET2 mutations did not significantly affect the OS in patients with MDS. Then, different subgroup analyses were also performed. The results of one subgroup analysis showed that in patients treated with HMAs [27, 30], the pooled HR for the OS was 1.02 (95\% CI: 0.77-1.35, $\mathrm{p}=0.89, \mathrm{I}^{2}=0.0 \%$ ) (Figure 3a). Also, in this subgroup, we analyzed the response rate to treatment with HMAs between patients with and without TET2 mutations, the results showed that when comparing patients with and without TET2 mutations, the pooled OR for the response rate was $1.73\left(95 \% \mathrm{CI}\right.$ : $\left.1.11-2.7, \mathrm{P}=0.016, \mathrm{I}^{2}=0.0 \%\right)$, which suggested that TET2 mutations might predict the of response to HMAs in patients with MDS patients (Figure $3 b$ ). Another subgroup analysis was performed in MDS patients who had been treated with hematopoietic stem-cell transplant (HSCT). The pooled HR for the OS was 1.56 (95\%CI: 0.88-2.76, $\mathrm{p}=0.125, \mathrm{I}^{2}=49.4 \%$ ) when comparing patients with TET2 mutations to those without (Figure 4a) In addition, a subgroup analysis was conducted in the WHO classified CMML patients, the pooled HR for OS was 0.93 (95\% CI: 0.44-1.98, $\mathrm{P}=0.849, \mathrm{I}^{2}=77.8 \%$ ) (Figure $4 \mathrm{~b}$ ). The data indicated that TET2 mutations did not significantly affect the OS in WHO classified CMML patients. 


\section{Prognostic impact of TET2 expression levels in patients with MDS}

Studies $[22,23]$ focused on the role of the TET2 expression level on the prognosis of MDS patients. The pooled HR for the OS was 1.68 (95\% CI: $1.20-2.34$, $\left.\mathrm{P}=0.002, \mathrm{I}^{2}=44.3 \%\right)$ in the comparison of TET2 low expression with TET2 high expression (Figure 5). Because of a lack of data, we could not analyze the effect of the TET2 expression level on the EFS. However, Santamarria et al (2012) [23] showed that the treatment-free survival (TFS, $\mathrm{P}<0.001)$ and progression-free survival $(\mathrm{p}=0.001)$ were shorter in the TET2 low expression level group than in the TET2 high expression level group. The results of Scopim-Ribeiro et al (2015) [22] suggested that a reduced TET2 high expression negatively impacted the event-free survival (EFS, $\mathrm{P} \leq 0.05$ ).

\section{Sensitivity analysis and publication bias}

We conducted a sensitivity analysis by omitting one study at a time to assess the effect of the study quality on the stability of this meta-analysis. Only studies analyzing the role of TET2 mutations on the prognosis were included in the sensitivity analysis. As shown in Figure 6, no individual study had a predominant influence on the overall HR. The Begg plots were largely symmetric, which indicated there was no evidence for significant publication bias in this meta-analysis.

\section{DISCUSSION}

TET2 is an epigenetic enzyme that is capable of converting DNA 5-methylcytosine $(5 \mathrm{mc})$ to 5 -hydroxymethylcytosine $(5 \mathrm{hmc})$. TET2 mutations are a common event in a spectrum of myeloid malignancies

\section{2 articles identified through database searching (PubMed, EMBASE, Medline, the Cochrane central, web of science)}

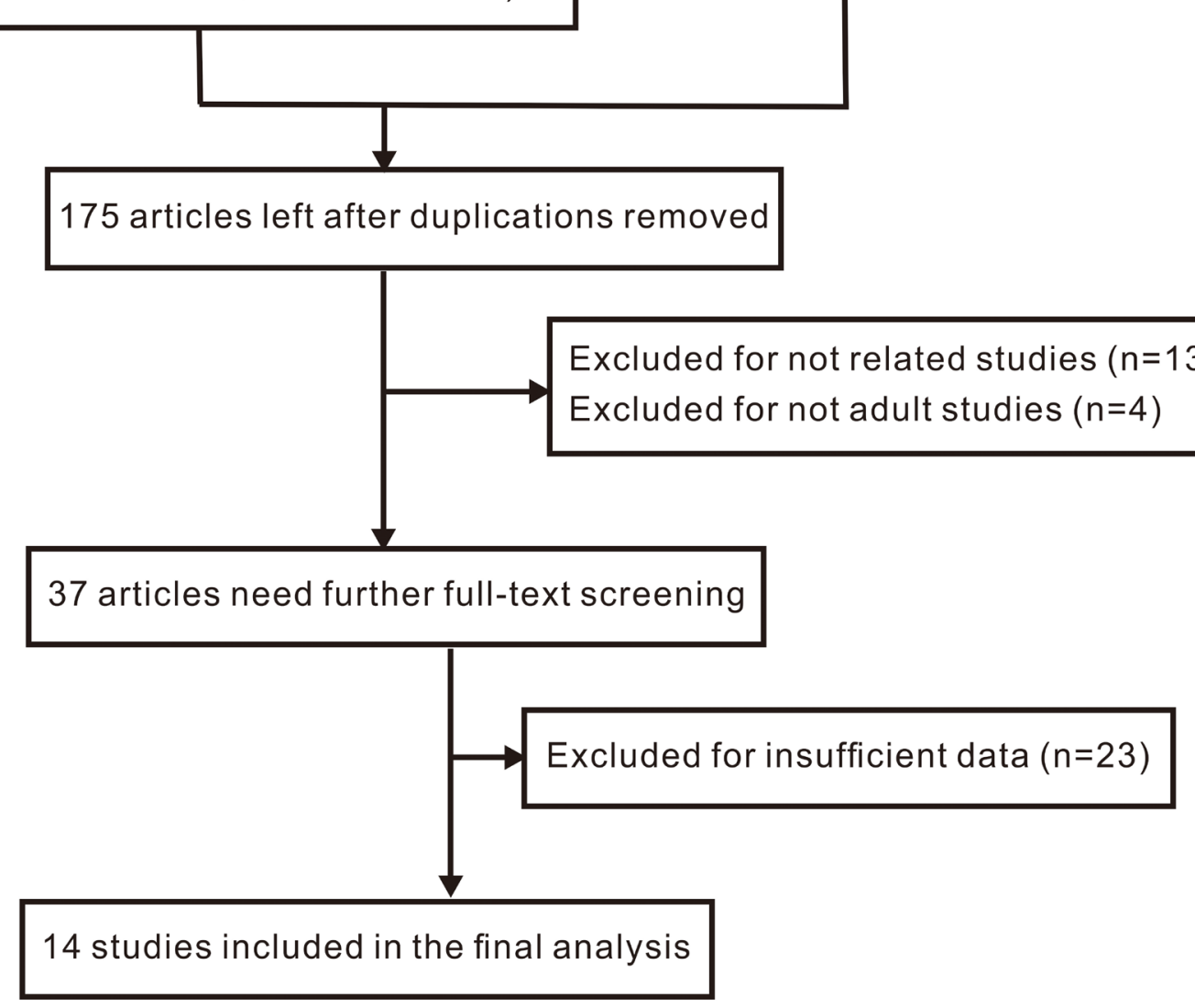

3 additional record identified through relevant references

Figure 1: Flow diagram of selection process in the meta-analysis. 
Table 1: Summary of the data extracted from the 12 studies included

\begin{tabular}{|c|c|c|c|c|c|c|c|c|c|c|c|c|c|c|}
\hline Study & $\begin{array}{l}\text { BEJAR et al } \\
\text { (2014)[29] }\end{array}$ & $\begin{array}{l}\text { KOSMIDER et al } \\
(2009)[16]\end{array}$ & $\begin{array}{c}\text { BRAUN et } \\
\text { al (2011) } \\
{[30]}\end{array}$ & $\begin{array}{l}\text { SMITH et al } \\
(2010)[17]\end{array}$ & $\begin{array}{l}\text { X.Liu et al } \\
\text { (2013)[31] }\end{array}$ & $\begin{array}{c}\text { Kohlmann } \\
\text { et al (2010) } \\
{[32]}\end{array}$ & $\begin{array}{c}\text { J. Wang et } \\
\text { al (2012) } \\
{[33]}\end{array}$ & $\begin{array}{l}\text { O.Kosmlder et al } \\
\quad(2009)[12]\end{array}$ & $\begin{array}{l}\text { Bejai } e t \text { al } \\
\text { (2011)[34] }\end{array}$ & $\begin{array}{c}\text { Kim et al (2015) } \\
{[20]}\end{array}$ & $\begin{array}{l}\text { Christopeit } e t \\
\text { al (2015)[35] }\end{array}$ & $\begin{array}{l}\text { Bejar et al } \\
\text { (2014)[36] }\end{array}$ & $\begin{array}{c}\text { Santamaria } \\
\text { et al (2012) } \\
{[37]}\end{array}$ & $\begin{array}{c}\text { Scopim- } \\
\text { Ribeiro et al } \\
\text { (2014)[38 } \\
\text { ] }\end{array}$ \\
\hline Journal & Blood & Blood & Blood & Blood & $\begin{array}{l}\text { Leukemia \& } \\
\text { Lymphoma }\end{array}$ & J Clin Oncol & $\begin{array}{l}\text { Leukemia } \\
\text { Research }\end{array}$ & Haematologica & $\begin{array}{l}\text { N Engl J } \\
\text { Med }\end{array}$ & $\begin{array}{l}\text { Bone Marrow } \\
\text { Transplantation }\end{array}$ & $\begin{array}{c}\text { European } \\
\text { Journal of } \\
\text { Haematology }\end{array}$ & J Clin Oncol & $\begin{array}{c}\text { Ann } \\
\text { Hematol }\end{array}$ & $\begin{array}{c}\text { European } \\
\text { Journal of } \\
\text { Haematology }\end{array}$ \\
\hline Patients(n) & 213 & 96 & 39 & 355 & 61 & 81 & 153 & 88 & 439 & 52 & 62 & 87 & 193 & 64 \\
\hline TET2 status & 58 mutations & 22 mutations & $\begin{array}{c}13 \\
\text { mutations }\end{array}$ & 55 mutations & 10 mutations & 36 mutations & $\begin{array}{c}35 \\
\text { mutations }\end{array}$ & 44 mutations & $\begin{array}{c}90 \\
\text { mutations }\end{array}$ & 8 mutations & 13 mutations & 11 mutations & $\begin{array}{c}96 \text { low gene } \\
\text { expression } \\
\text { level }\end{array}$ & $\begin{array}{c}45 \text { low gene } \\
\text { expression } \\
\text { level }\end{array}$ \\
\hline Age(years) & $\geq 70 \mathrm{y}(103)$ & $71.5(63.5-79)$ & $71(54-88)$ & 64.4(17.0-96.) & $58(23-80)$ & $\begin{array}{l}72.8(40- \\
85.5)\end{array}$ & $51(16-81)$ & $76(54-93)$ & $\geq 75 \mathrm{y}(123)$ & $52(18-73)$ & $71(20-90)$ & $58(19-73)$ & $76(31-91)$ & $68(16-90)$ \\
\hline Criterion & FAB & $\mathrm{FAB} / \mathrm{WHO}$ & WHO & WHO & WHO & WHO & WHO & WHO & FAB & WHO & WHO & FAB & WHO & WHO \\
\hline Therapy & $\begin{array}{l}\text { AZA alone(42) } \\
\text { DEC alone(144) } \\
\text { DEC+other(27) }\end{array}$ & $\begin{array}{c}\text { None }(40) \\
\text { Red blood cell } \\
\text { transfusions(26) } \\
\text { Erythropoiesis- } \\
\text { stimulating agent } \\
\text { with or without } \\
\text { G-CSF(33) } \\
\text { Lenalidomide/ } \\
\text { thalidomide(5) } \\
\text { Demethylating } \\
\text { agents }(5) \\
\text { Low doses } \\
\text { or intensive } \\
\text { chemotherapy(7) }\end{array}$ & $\mathrm{DAC}(39)$ & $\begin{array}{c}\text { None/BSC(211) } \\
\text { EPO/GCSF(29) } \\
\text { 5-azacitidine(14) } \\
\text { Intensive chemo } \\
\text { and transplant }(82) \\
\text { Treatment data not } \\
\text { available(19) }\end{array}$ & NR & NR & NR & NR & NR & $\begin{array}{c}\text { HMT(43) } \\
\text { SCT(8) } \\
\text { Intensive } \\
\text { chemotherapy } \\
(1)\end{array}$ & $\begin{array}{l}\text { Allogeneic } \\
\text { hematopoietic } \\
\text { stem cell } \\
\text { transplantation } \\
(62)\end{array}$ & $\begin{array}{l}\text { Stem-Cell } \\
\text { Transplantation } \\
(87)\end{array}$ & $\begin{array}{c}\text { Without any } \\
\text { treatment }\end{array}$ & $\begin{array}{c}\text { Without any } \\
\text { treatment }\end{array}$ \\
\hline
\end{tabular}

WHO: World Health Organization; FAB: French-American-British; TET2: Tet methylcytosine dioxygenase 2. NR: not report.

Table 2: Quality assessment of individual study

\begin{tabular}{|c|c|c|c|c|}
\hline Study & Selection & Comparability & Outcome & Score \\
\hline BEJAR et al (2014) [29] & $* * * *$ & $* *$ & $* *$ & $8 / 9$ \\
\hline $\begin{array}{l}\text { KOSMIDER et al (2009) } \\
{[16]}\end{array}$ & $* * * *$ & $*$ & $* *$ & $7 / 9$ \\
\hline $\begin{array}{l}\text { BRAUN et al (2011) } \\
{[30]}\end{array}$ & $* * * *$ & $*$ & $* * *$ & $8 / 9$ \\
\hline SMITH et al (2010) [17] & $* * * *$ & $*$ & $* * *$ & $8 / 9$ \\
\hline X.Liu et al (2013) [31] & $* * * *$ & $* *$ & $* * *$ & $9 / 9$ \\
\hline $\begin{array}{l}\text { Kohlmann et al (2010) } \\
\text { [32] }\end{array}$ & $* * * *$ & & $* * *$ & $7 / 9$ \\
\hline J. Wang et al (2012) [33] & $* * * *$ & & $* * *$ & $7 / 9$ \\
\hline $\begin{array}{l}\text { O.Kosmlder et al (2009) } \\
\text { [12] }\end{array}$ & $* * * *$ & & $* * *$ & $7 / 9$ \\
\hline Bejai et al (2011) [34] & $* * * *$ & & $* * *$ & $7 / 9$ \\
\hline Kim et al (2015) [20] & $* * * *$ & & $* *$ & $6 / 9$ \\
\hline $\begin{array}{l}\text { Christopeit et al (2015) } \\
\text { [35] }\end{array}$ & $* * *$ & $* *$ & $* * *$ & $8 / 9$ \\
\hline Bejar et al (2014) [36] & $* * * *$ & $* *$ & $* *$ & $8 / 9$ \\
\hline $\begin{array}{l}\text { Santamaria et al(2012) } \\
{[37]}\end{array}$ & $* * * *$ & & $* * *$ & $7 / 9$ \\
\hline $\begin{array}{l}\text { Scopim-Ribeiro et al } \\
\text { (2014) [38] }\end{array}$ & $* * * *$ & $* *$ & $* *$ & $8 / 9$ \\
\hline
\end{tabular}

(Selection: Representativeness of exposed cohort, Selection of no exposed cohort, Ascertainment of exposure, Outcome not present at start; Outcome: Assessment of outcome, Follow-up length, Follow-up adequacy).

Newcastle-Ottawa Quality Assessment Scale: study can have one star (*) for meeting each criterion, except that comparability (design or analysis) can have a maximum of two stars $(* *)$. 


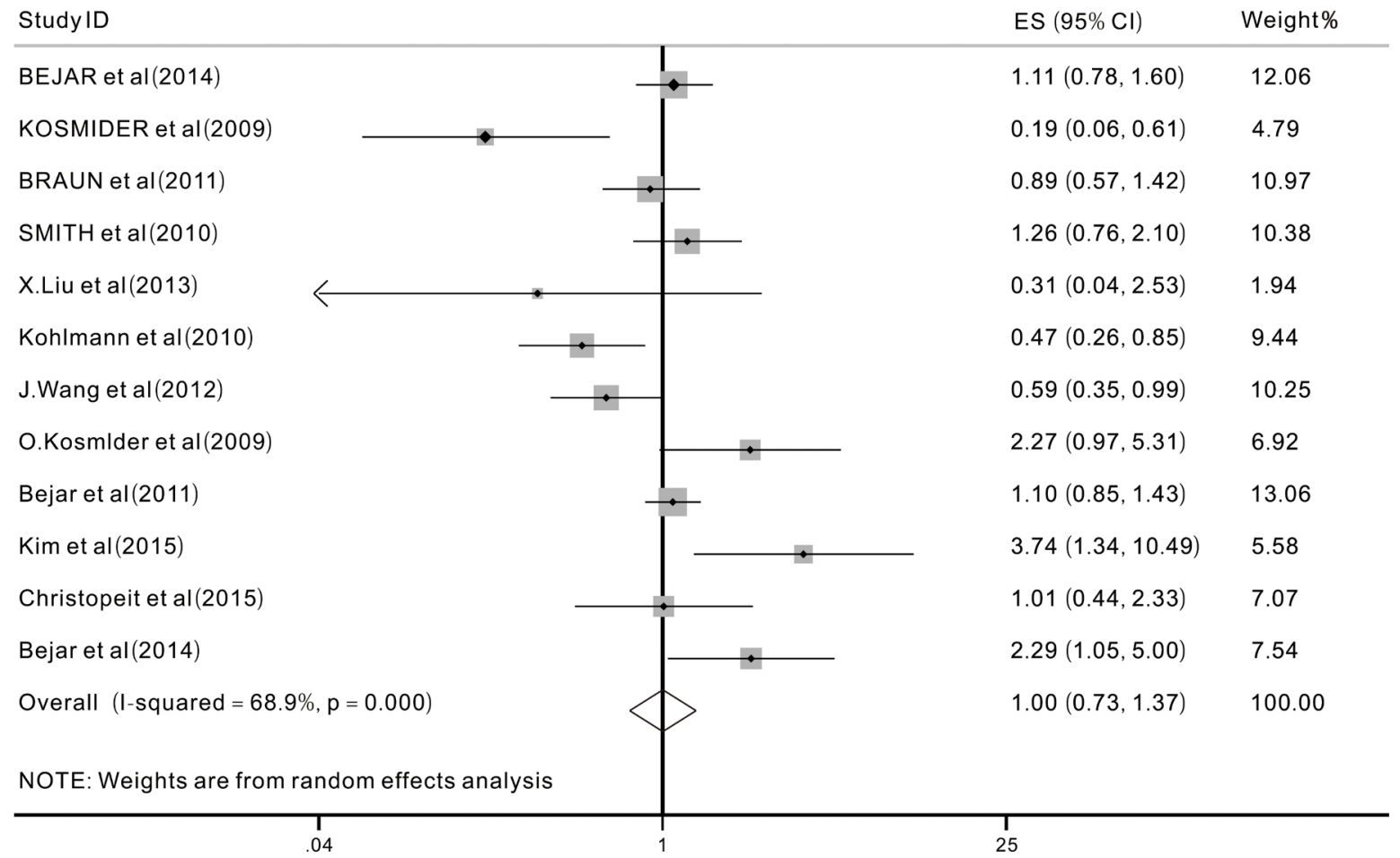

Figure 2: Forest plots of the hazard ratios (HRs) and $95 \%$ confidence intervals for overall survival (OS) in MDS patients. The size of the blocks or diamonds represents the weight, the length of the straight line represents the width of $95 \%$ CI.

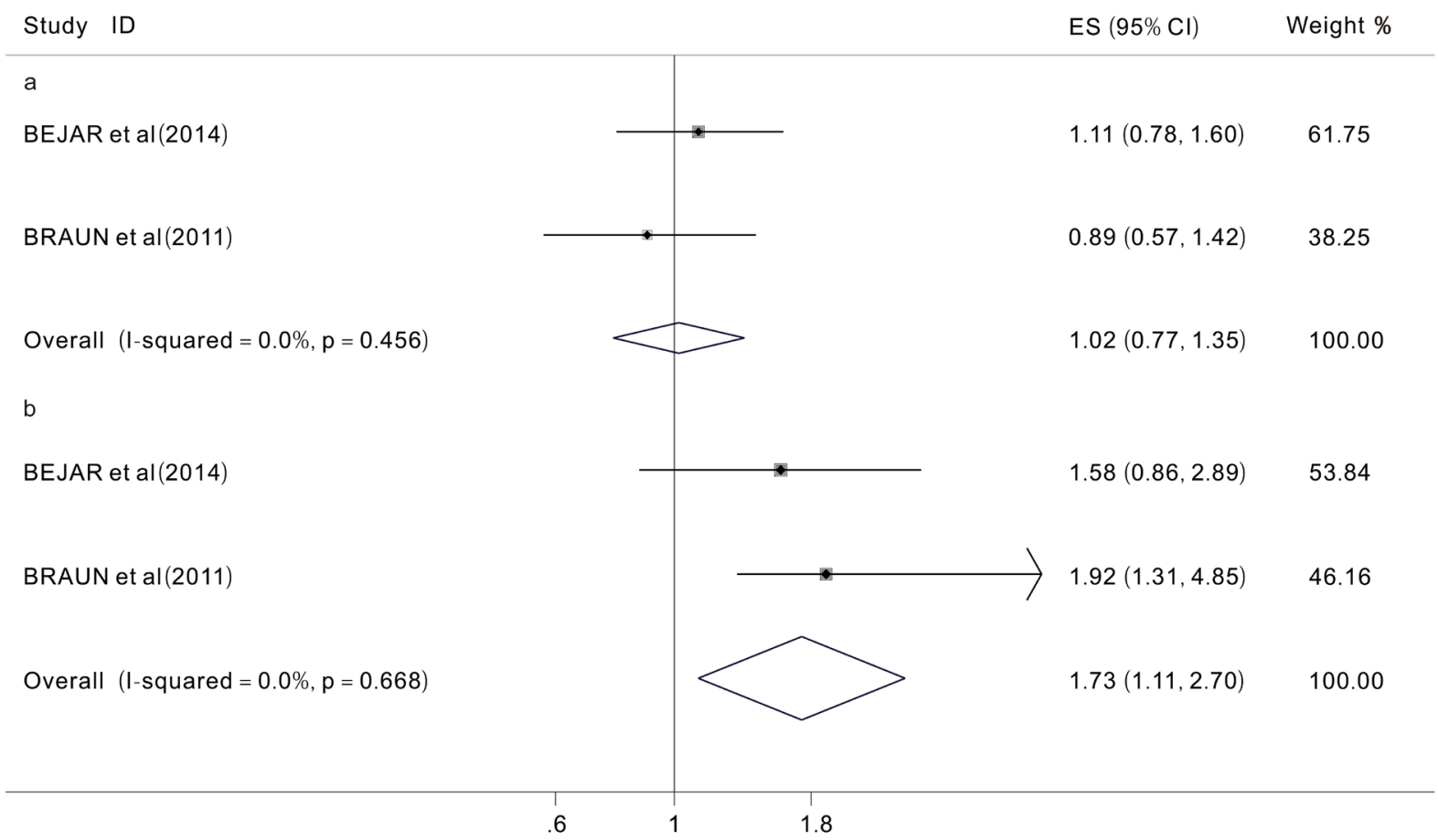

Figure 3: Forest plots of the hazard ratios (HRs) and $95 \%$ confidence intervals for overall survival (OS) in MDS patients treated with HMAs (a) and the hazard ratios (ORs) and 95\% confidence intervals for response rates in MDS patients treated with HMAs (b). The size of the blocks or diamonds represents the weight, the length of the straight line represents the width of $95 \% \mathrm{CI}$. 


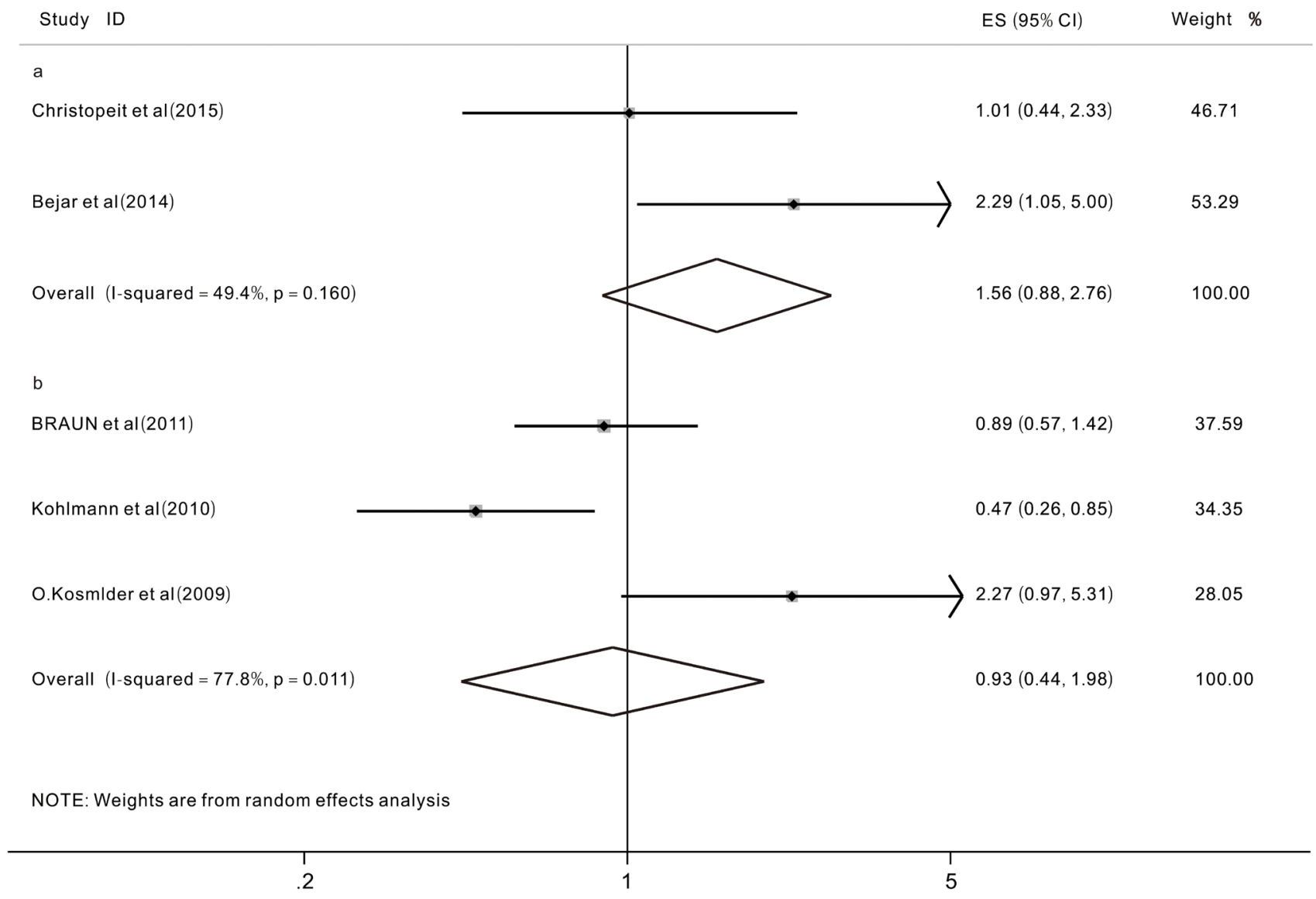

Figure 4: Forest plots of the hazard ratios (HRs) and 95\% confidence intervals for overall survival (OS) in MDS patients treated with HSCT (a) and the hazard ratios (HRs) and 95\% confidence intervals for overall survival (OS) in WHO-classified CMML patients (b). The size of the blocks or diamonds represents the weight, the length of the straight line represents the width of $95 \% \mathrm{CI}$.

\begin{tabular}{l} 
Study ID \\
Santamar" aa et al(2012) \\
Scopim-Ribeiro et al (2014) \\
Overall (I-squared $=44.3 \%, p=0.180)$ \\
\hline .129
\end{tabular}

Figure 5: Forest plots of the hazard ratios (HRs) and 95\% confidence intervals for overall survival (OS) according to the TET2 expression levels of patients with MDS patients. The size of the blocks or diamonds represents the weight, the length of the straight line represents the width of $95 \%$ CI. 
Meta-analysis estimates, given named study is omitted

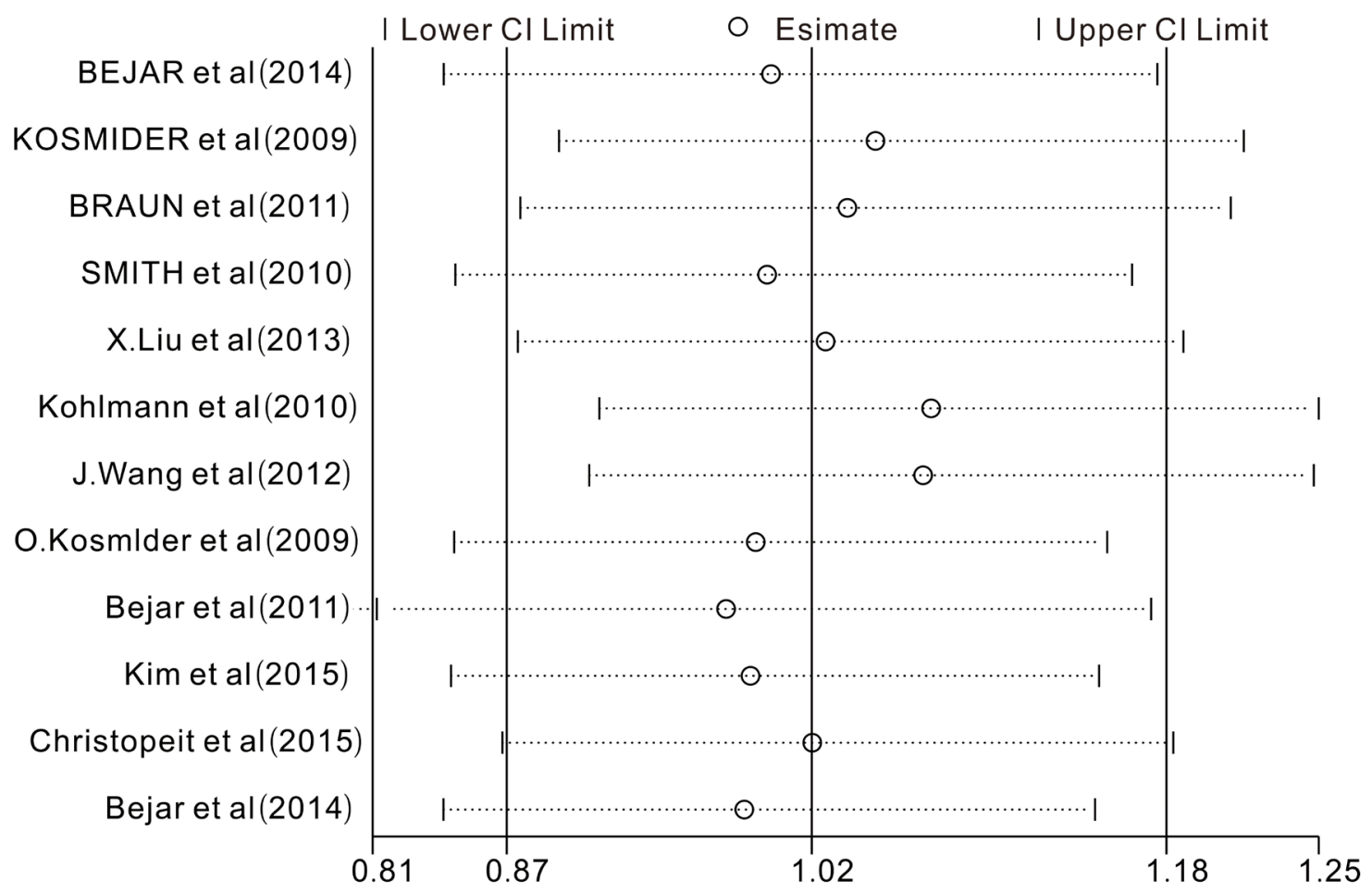

Figure 6: Sensitivity analysis. The middle vertical axis represents the pooled HR and the 2 vertical axes indicate the corresponding 95\% CI. Each hollow circle represents the pooled HR when the left study was omitted in this meta-analysis, and the 2 ends of every broken line indicate the $95 \% \mathrm{CI}$.

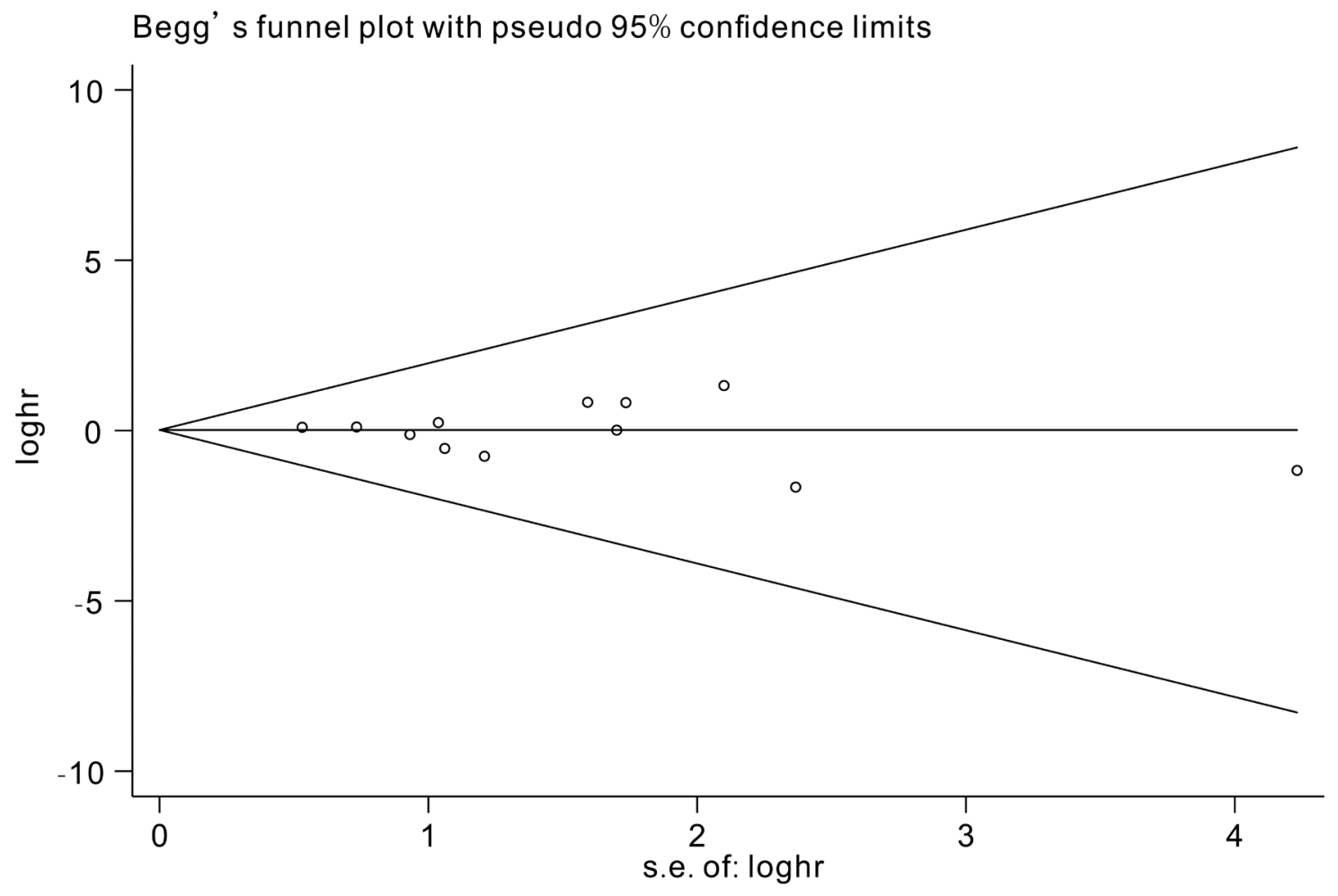

Figure 7: Begg's funnel plot for publication bias analysis. Each point represents a separate study and horizontal line represents the mean effect size. Studies were distributed symmetrically and suggested there were no significant biases exist. 
and are one of the most frequent gene mutations in MDS and CMML [14, 31]. TET2 mutations compromise the hydroxymethyl-catalytic activity of the epigenetic enzyme and can lead to low levels of 5-hmc in genomic DNA. This is thought to be one of the mechanisms through which TET2 mutations contribute to the pathogenesis of MDS and CMML. Additionally, Wang et al [32] reported that TET2 with $W T 1$ and $I D H 1 / I D H 2$ increased the 5-hmc levels. Although many studies have assessed the prognostic implication of TET2 mutations in patients with MDS, the results are inconsistent and some are even conflicting [12, 15, 16, 20, 21, 24-30]. O.Kosmider et al (2009) [16] showed that TET2 mutations were an independent favorable prognostic factor in MDS and were frequent and adverse events in CMML [15]. SMITH et al (2010) [12] reported that TET2 mutations had no prognostic value for patients with MDS and CMML and Kim et al (2015) [20] indicated that TET2 mutations were a poor prognostic factor in patients with MDS. As a result, the exact implication of TET2 mutations on MDS still needed illuminating. Therefore, we performed a metaanalysis to exactly delineate the prognostic role of TET2 mutations in MDS and CMML patients.

In this meta-analysis, 14 studies covering a total of 1983 patients were included. The results were as follows: the overall $\mathrm{HR}$ for the OS was 1.00 (95\% CI: 0.74-1.37), which indicated that the TET2 mutations did not significantly affect the OS in patients with MDS. Although the heterogeneity was large $\left(I^{2}=68.9 \%\right)$, the sensitivity analysis indicated the stability of our analysis, which demonstrated that the results of the meta-analysis were reliable. Our results are consistent with SMITH et al (2010) [12] and some other studies. Then, different subgroup analyses were conducted. The pooled HR for the OS was 0.93 (95\% CI: 0.44-1.98) in WHO classified CMML patients. The results demonstrated that TET2 mutations had no significant impact on OS in patients with CMML. This is consistent with the findings by BRAUN et al (2011) [27], but it is inconsistent with the reports by Kohlmann et al (2010) [25] and O.Kosmlder et al (2009) [15]. Although our results integrated data from multiple studies $[22,25,30]$, which could be more reliable, the heterogeneity of out meta-analysis was extreme $\left(\mathrm{I}^{2}=77.8 \%\right)$ and the number of studies included in the analysis was limited.

DNA HMAs are very effective drugs that have been approved for treating patients with MDS and HSCT is the only potentially curative therapeutic option in patients with MDS. Hence, we also performed subgroup analyses in patients who were treated with HMAs and HSCT, The results showed that the pooled HR for the OS was 1.02 (95\% CI: 0.77-1.35) and the pooled OR for the response rate was 1.73 (95\% CI: 1.11-2.70) for patients who were treated with HMAs. Although a randomized phase 3 study by Fenaux et al (2009) [33] indicated that HMAs conferred an overall survival benefit compared with supportive care, HMAs did not prolong the OS of MDS patients with TET2 mutations compared to those without in studies $[27,30]$. Our results were consistent with the results of a couple studies [27, 30]. Additionally, our results showed that MDS patients with TET2 mutations had an increased response rates to HMAs compared with WT and this is consistent with many prior studies [27, 30]. Additionally, in patients who received HSCT, we found that TET2 mutations had no significant impact on the OS. However, we only included two studies in this subgroup analysis, and the exact role of TET2 mutations in MDS patients treated with HSCT requires further investigation.

It has been reported that TET2 haploinsufficiency may be sufficient to confer myeloid transformation and impair hematopoietic cell differentiation. Hence, we conducted a meta-analysis to investigate the TET2 mRNA expression. Two studies were included in the analysis. The pooled HR for the OS was 1.68 (95\%CI: 1.20-2.34) when comparing TET2 low expression level with TET2 high expression. The results indicated that TET2 low expression was associated with an unfavorable prognosis in MDS patients. This is consistent with prior studies [22, 23]. However, there are three main limitations in our metaanalysis. First, the analysis was based on observational studies rather than on randomized trials or prospective studies. Second, the analysis, especially the subgroup analysis covered a small number of MDS patients. Third, we could not avoid potential heterogeneity and publication bias in the meta-analysis.

\section{CONCLUSION}

Considering the limitations mentioned above, our meta-analysis shows that TET2 mutations have no significant impact on the OS of MDS patients. Additionally, in WHO- classified CMML patients and patients treated with HMAs or stem-cell transplantation subgroups, TET2 mutations did not have prognostic value. However, patients with TET2 mutations achieved higher response rates to HMAs than did those without mutations and a low TET2 expression level in patients with MDS was significantly associated with a poor OS. The results suggest that TET2 mutations may be predictive of the response to HMAs in patients with MDS and TET2 gene expression level may provide additional information for a suitable molecular risk-stratification in MDS.

\section{MATERIALS AND METHODS}

\section{Search strategy}

The search for eligible studies was conducted in PubMed, Embase, Medline, the Cochrane Library and Web of Science with the following search terms: "TET2" or "tet methylcytosine dioxygenase 2" or "tet oncogene family member 2" and "MDS" or "myelodysplastic 
syndrome" or "myelodysplasia" or "preleukemia" or "CMML" or "Chronic myelomonocytic leukemia". The search was restricted to human studies, and free articles with no language limitation. Relevant papers published between 2007 and 2016 were obtained by two independent reviewers (Y.L and Z.J.). We also reviewed the references for missing information.

\section{Selection criteria}

We included trials if they met the following criteria: (1) published between January 01, 2007 and July 31, 2016 as original articles; (2) assessed the association between the TET2 status and prognosis in MDS and CMML patients; and (3) offered detailed survival information from which we could calculate the hazard ratios (HRs) as well as the corresponding 95\% confidential intervals (CIs) or event-free survival (EFS) based on the following TET2 status: TET2 mutations/wild-type TET2 or TET2 low expression level/ TET2 high expression. The OS was measured from the date of the first sample collection to the time of death from any causes or to the time at the last follow-up (censored). The EFS was defined as remission, induction failure, relapse or death for any reason from entry in the trial. We excluded studies that were published in the abstract form, review articles, case reports, only analyzing pediatric patients or studies with unavailable or incomplete data. However, we included a letter to the editor in our meta-analysis because it met all of the inclusion criteria.

\section{Data extraction}

Two reviewers (Y.L and Z.L.) independently extracted data from the articles. Disagreements were resolved by discussion until a consensus was achieved. The following data were extracted from the articles: the name of the first author, year of publication, journal, number of patients, number of TET2 mutations / TET2 low expression level, age, criteria for classification of MDS and CMML, therapeutic method and outcomes such as the including hazard ratios (HRs) or response ratios, and their 95\% confidence intervals (CIs) for the OS based on the TET2 status. When outcomes published in the original articles were only survival curves, the HRs and 95\% CIs were calculated by the methods proposed by Parmar et al (1998) [34] and Hotta et al (2004) [35]. If HRs of the univariate analysis and multivariate analyses were reported, the results of the multivariate analysis including other variables should be preferentially considered because they could be more accurate.

\section{Quality assessment}

Two reviewers (Y.L and Z.L.) independently assessed the study quality. The Newcastle-Ottawa (NOS) [36] was used to score the quality of each cohort study.
This scale has nine items that are classified into the following three major categories: selection (four items), comparability (two items) and outcome (three items). The overall quality score was classified the following into 3 types: high quality (7-9 scores), intermediate quality (4-6 scores), and low quality (1-3 scores). Any discrepancies were resolved among the authors.

\section{Statistical analysis}

All statistical analyses were performed using Stata ver.12 software (College Station, TX, USA). For the OS and response rate, the HRs or ORs and their 95\% CIs were directly extracted from the included studies or indirectly calculated from the reported events, the P value in the logrank test or from the published Kaplan-Meier curves [3739]. The prognostic role of TET2 mutations on the OS and response ratio were assessed by estimation of the pooled HRs and the respective $95 \%$ CIs with the inverse variance method in total population and subgroups [40]. The statistical heterogeneity of the studies was assessed by the chi-square based Q-test and quantified with the $\mathrm{I}^{2}$ statistic $\left(\mathrm{I}^{2}=0-25 \%\right.$; no heterogeneity; $\mathrm{I}^{2}=25-50 \%$; moderate heterogeneity; $\mathrm{I}^{2}=50-75 \%$; large heterogeneity; and $\mathrm{I}^{2}=75$ $100 \%$; extreme heterogeneity). When the heterogeneity across studies was identified $(>50 \%)$, the random effects model (the DerSimonian and Laird method) was used, otherwise, the fixed-effect model (the Mantel-Haenszel method) was used [41]. Additionally, sensitivity analysis was conducted to investigate the influence of one single study on the overall HR and Begg's and Egger's tests were conducted to detect possible publication bias [40, 41]. A two-tailed P-value less than 0.05 was considered statistically significant. All the statistical analyses were done by Y.L and K.C.

\section{Author contributions}

Y.L. had the idea for the study and wrote the article. Y.L. and Z.L. designed the study. Z.F and Z.L. helped modify and improve the tables and figures. K.C. assisted with the statistical analysis. B.X. and Y.M. were the advisors.

\section{ACKNOWLEDGMENTS AND FUNDING}

We thank all patients and clinical investigators who were involved in the studies selected for this meta-analysis. This work was financially supported by National Nature Science Foundation of China, PR China (No.81428003) and The Natural Science Foundation of Guangdong Province (No.2014A030313355).

\section{CONFLICTS OF INTEREST}

We declare no competing interests. 


\section{REFERENCES}

1. Tefferi A, Vardiman JW. Myelodysplastic syndromes. N Engl J Med. 2009; 361:1872-1885.

2. Nolte F, Hofmann WK. Myelodysplastic syndromes: molecular pathogenesis and genomic changes. Ann Hematol. 2008; 87:777-795.

3. Greenberg PL, Attar E, Bennett JM, Bloomfield CD, De Castro CM, Deeg HJ, Foran JM, Gaensler K, GarciaManero G, Gore SD, Head D, Komrokji R, Maness LJ, et al. Myelodysplastic syndromes: clinical practice guidelines in oncology. J Natl Compr Canc Netw. 2013; 11:838-874.

4. Greenberg P, Cox C, LeBeau MM, Fenaux P, Morel P, Sanz G, Sanz M, Vallespi T, Hamblin T, Oscier D, Ohyashiki K, Toyama K, Aul C, et al. International scoring system for evaluating prognosis in myelodysplastic syndromes. Blood. 1997; 89:2079-2088.

5. Shih AH, Levine RL. Molecular biology of myelodysplastic syndromes. Semin Oncol. 2011; 38:613-620.

6. Bejar R, Levine R, BL Ebert. Unraveling the molecular pathophysiology of myelodysplastic syndromes. J Clin Oncol. 2011; 29:504-515.

7. Vardiman JW, Harris NL, Brunning RD. The World Health Organization (WHO) classification of the myeloid neoplasms. Blood. 2002; 100:2292-3000.

8. Tahiliani M, Koh KP, Shen Y, Pastor WA, Bandukwala H, Brudno Y, Agarwal S, Iyer LM, Liu DR, Aravind L, Rao A. Conversion of 5-methylcytosine to 5-hydroxymethylcytosine in mammalian DNA by MLL partner TET1. Science. 2009; 324:930-935.

9. Ko M, Huang Y, Jankowska AM, Pape UJ, Tahiliani M, Bandukwala HS, An J, Lamperti ED, Koh KP, Ganetzky P, Liu XS, Aravind L, Agarwal S, et al. Impaired hydroxylation of 5-methylcytosine in myeloid cancers with mutant TET2. Nature. 2010; 468:839-843.

10. Ito S, D'Alessio AC, Taranova OV, Hong K, Sowers LC, Zhang Y. Role of Tet proteins in $5 \mathrm{mC}$ to $5 \mathrm{hmC}$ conversion, ES-cell selfrenewal and inner cell mass specification. Nature. 2010; 466:1129-1133.

11. Tefferi A, Lim KH, Abdel-Wahab O, Lasho TL, Patel J, Patnaik MM, Hanson CA, Pardanani A, Gilliland DG, Levine RL. Detection of mutant TET2 in myeloid malignancies other than myeloproliferative neoplasms: CMML, MDS, MDS/MPN, and AML. Leukemia. 2009; 23:1343-1345.

12. Smith AE, Mohamedali AM, Kulasekararaj A, Lim ZY, Gäken J, Lea NC, Przychodzen B, Mian SA, Nasser EE, Shooter C, Westwood NB, Strupp C, Gattermann N, et al. Next-generation sequencing of the TET2 gene in 355 MDS and CMML patients reveals low-abundance mutant clones with early origins, but indicates no definite prognostic value. Blood. 2010; 116:3923-3932.

13. Rocquain J, Carbuccia N, TrouplinV, Raynaud S, Murati A, Nezri M, Tadrist Z, Olschwang S, Vey N, Birnbaum D,
Gelsi-Boyer V, Mozziconacci M. Combined mutations of ASXL1, CBL, FLT3, IDH1, IDH2, JAK2, KRAS, NPM1, NRAS, RUNX1, TET2 and WT1 genes in myelodysplastic syndromes and acute myeloid leukemias. BMC Cancer. 2010; 401:1471-2407.

14. Langemeijer SM, Kuiper RP, Berends M, Knops R, Aslanyan MG, Massop M, Stevens-Linders E, Hoogen P, Kessel AG, Raymakers RA, Kamping EJ, Verhoef GE, Verburgh E, et al. Acquired mutations in TET2 are common in myelodysplastic syndromes. Nat Genet. 2009; 41: 838-842.

15. Kosmider O, Gelsi-Boyer V, Ciudad M, Racoeur C, Jooste V, Vey N, Quesnel B, Fenaux P, Bastie J, Beyne-Rauzy O, Tamatoulas A, Dreyfus F, Ifrah N, et al. TET2 gene mutation is a frequent and adverse event in chronic myelomonocytic leukemia. Haematologica. 2009; 94: 1676-1681.

16. Kosmider O, Gelsi-Boyer V, Cheok M, Grabar S, DellaValle V, Picard F, Viguié F, Quesnel B, Beyne-Rauzy O, Solary E, Vey N, Hunault-Berger M, Fenaux P, et al. TET2 mutation is an independent favorable prognostic factor in myelodysplastic syndromes (MDSs). Blood. 2009; 114:3285-3291.

17. Jankowska AM, Szpurka H, Tiu RV, Makishima H, Afable M, Huh J, O'Keefe CL, Ganetzky R, McDevittand MA, Maciejewski JP. Loss of heterozygosity 4q24 and TET2 mutations associated with myelodysplastic/myelo proliferative neoplasms. Blood. 2009; 113:6403-6410.

18. Itzykson R, Kosmider O, Cluzeau T, Mas VM, Dreyfus F, Beyne-Rauzy O, Quesnel B, Vey N, Gelsi-Boyer V, Raynaud S, Preudhomme C, Adès L, Fenaux P, et al. Impact of TET2 mutations on response rate to azacitidine in myelodysplastic syndromes and low blast count acute myeloid leukemias. Leukemia. 2011; 25:1147-1152.

19. Delhommeau F, Dupont S, Della Valle V, James C, Trannoy S, Massé A, Kosmider O, Le Couedic JP, Robert F, Alberdi A, Lécluse Y, Plo I, Dreyfus FJ, et al. Mutation in TET2 in myeloid cancers. N Engl J Med. 2009; 360:2289-2301.

20. Kim M, Yahng SA, Kwon A, Park J, Jeon YW, Yoon JH, Shin SH, Lee SE, Cho BS, Eom KS, Lee S, Min CK, Kim HJ, et al. Mutation in TET2 or TP53 predicts poor survival in patients with myelodysplastic syndrome receiving hypomethylating treatment or stem cell transplantation. Bone Marrow Transplant. 2015; 50:1132-1134.

21. Wang J, Ai X, Gale RP, Xu Z, Qin T, Fang L, Zhang H, Pan L, Hu N, Zhang Y, Xiao Z. TET2, ASXL1 and EZH2 mutations in Chinese with myelodysplastic syndromes. Leuk Res. 2013; 37:1110-1016.

22. Scopim-Ribeiro R, Machado-Neto JA, Campos PM, Silva CAM, Favaro P, Lorand-Metze I, Costa FF, Saad STO, Traina F. Ten-Eleven-Translocation 2 (TET2) is downregulated in myelodysplastic syndromes. Eur J Haematol. 2015; 94:413-418.

23. Santamaría C, Ramos F, Puig N, Barragán E, Paz P, Pedro C, Insunza A, Tormo M, Cañizo C, Diez-Campelo M, Xicoy B, Salido E, Sánchez del Real J, et al. Simultaneous analysis 
of the expression of 14 genes with individual prognostic value in myelodysplastic syndrome patients at diagnosis: WT1 detection in peripheral blood adversely affects survival. Ann Hematol. 2012; 91:1887-1895.

24. Liu X, Zhang G, Yi Y, Xiao L, Pei M, Liu S, Luo Y, Zhong $\mathrm{H}, \mathrm{Xu} \mathrm{Y}$, Zheng W, Shen J. Decreased 5-hydroxymethylcytosine levels are associated with TET2 mutation and unfavorable overall survival in myelodysplastic syndromes. Leuk Lymphoma. 2013; 54:2466-2473.

25. Kohlmann A, Grossmann V, Haferlach C, Kazak B, Schindela S, Klein H, Weiss T, Dicker F, Schnittger S, Dugas M, Kern W, Haferlach T. Next-generation sequencing technology reveals a characteristic pattern of molecular mutations in $72.8 \%$ of chronic myelomonocytic leukemia by detecting frequent alterations in TET2, CBL, RAS, and RUNX1. J Clin Oncol. 2010; 28:3858-3865.

26. Christopeit M, Badbaran A, Alawi M, Zabelina T, Zeck G, Wolschke C, Ayuk F, Kröger N. Correlation of somatic mutations with outcome after FLAMSA-busulfan sequential conditioning and allogeneic stem cell transplantation in patients with myelodysplastic syndromes. Eur J Haematol. 2016; 97:288-296.

27. Braun T, Itzykson R, Renneville A, Renzis B, Dreyfus F, Laribi K, Bouabdallah K, Vey N, Toma A, Recher C, Royer B, Joly B, Vekhoff A, et al. Molecular predictors of response to decitabine in advanced chronic myelomonocytic leukemia: A phase 2 trial. Blood. 2011; 118:3824-3831.

28. Bejar R, Stevenson KE, Caughey B, Lindsley RC, Mar BG, Stojanov P, Getz G, Steensma DP, Ritz J, Soiffer R, Antin JH, Alyea E, Armand P, et al. Somatic mutations predict poor outcome in patients with myelodysplastic syndrome after hematopoietic stem-cell transplantation. J Clin Oncol. 2014; 32:2691-2698.

29. Bejar R, Stevenson K, Abdel-Wahab O, Galili N, Nilsson B, Garcia-Manero G, Kantarjian H, Raza A, Levine RL, Neuberg D, Ebert BL. Clinical effect of point mutations in myelodysplastic syndromes. New Engl J Med. 2011; 364: 2496-2506.

30. Bejar R, Lord A, Stevenson K, Bar-Natan M, PérezLadaga A, Zaneveld J, Wang H, Caughey B, Stojanov P, Getz G, Garcia-Manero G, Kantarjian H, Chen R. TET2 mutations predict response to hypomethylating agents in myelodysplastic syndrome patients. Blood. 2014; 124:2705-2712.
31. Mullighan CG. TET2 mutations in myelodysplasia and myeloid malignancies. Nat Genet. 2009; 41:766-767.

32. Wang Y, Xiao M, Chen X, Chen L, Xu Y, Lv L, Wang P, Yang H, Ma S, Lin H, Jiao B, Ren R, Ye D, et al. WT1 recruits TET2 to regulate its target gene expression and suppress leukemia cell proliferation. Mol Cell. 2015; 57: 662-673.

33. Fenaux P, Mufti GJ, Hellstrom-Lindberg E, Santini V, Finelli C, Giagounidis A, Schoch R, Gattermann N, Sanz G, List A, Gore SD, Seymour JF, Bennett JM. International Vidaza High-Risk MDS Survival Study Group. Efficacy of azacitidine compared with that of conventional care regimens in the treatment of higher-risk myelodysplastic syndromes: a randomised, open-label, phase III study. Lancet Oncol. 2009; 10:223-232.

34. Parmar MK, Torri V, Stewart L. Extracting summary statistics to perform meta-analyses of the published literature for survival endpoints. Stat Med. 1998; 17:2815-2834.

35. Hotta K, Matsuo K, Ueoka H, Kiura K, Tabata M, Tanimoto M. Meta-analysis of randomized clinical trials comparing cisplatin to carboplatin in patients with advanced nonsmall-cell lung cancer. J Clin Oncol. 2004; 22:3852-3859.

36. Wells GA, Shea B, O'Connell D, Peterson J, Welch V, Losos M, Tugwell P. The Newcastle-Ottawa Scale (NOS) for assessing the quality of nonrandomised studies in metaanalyses. Available from: http:/www.ohri.ca/programs/ clinical_epidemiology/oxford .asp.

37. Tierney JF, Stewart LA, Ghersi D, Burdett S, Sydes MR. Practical methods for incorporating summary time-to-event data into meta-analysis. Trials. 2007; 8:16.

38. Higgins JP, Thompson SG, Deeks JJ, Altman DG. Measuring inconsistency in meta-analyses. Br Med J. 2003; 327:557-560.

39. DerSimonian R, Laird N. Meta-analysis in clinical trials. Contral Clin Trials. 1986; 7:177-188.

40. Begg CB, Mazumdar M. Operating characteristics of a rank correlation test for publication bias. Biometrics. 1994; 50:1088-1101.

41. Egge M, Smith GD, Schneider M, Minder C. Bias in metaanalysis detected by a simple, graphical test. Br Med J. 1997; 315: 629-634. 